\title{
Program för utbildning och forskning
}

Sveriges ordförandeskap 2018

$\mathbb{1}$ ) Nordiska ministerrådet

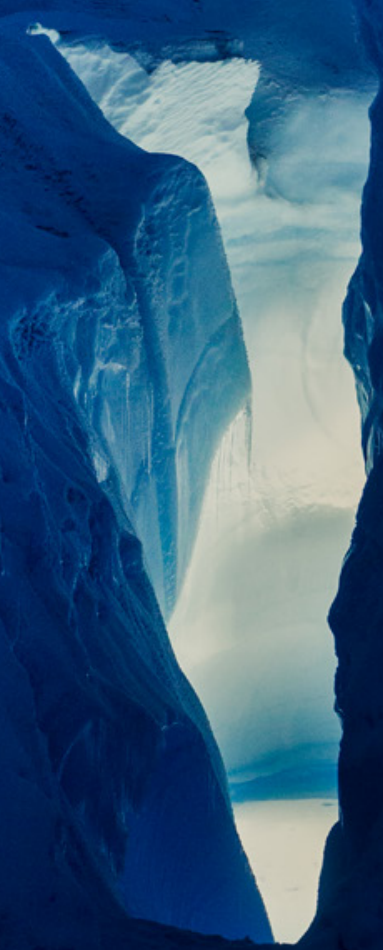




\section{Program för utbildning och forskning}

Sveriges ordförandeskap 2018 i Nordiska ministerrådet

ANP 2017:787

ISBN 978-92-893-5292-5 (PRINT)

ISBN 978-92-893-5293-2 (PDF)

ISBN 978-92-893-5294-9 (EPUB)

HTTP://DX.DOI.ORG/10.6027/ANP2017-787

(c) Nordiska ministerrådet 2017

Layout: Louise Jeppesen

Omslagsfoto: Paul Zizka - Visit Greenland

\section{Det nordiska samarbetet}

Det nordiska samarbetet är ett av världens mest omfattande regionala samarbeten. Det omfattar Danmark, Finland, Island, Norge och Sverige samt Färöarna, Grönland och Åland.

Det nordiska samarbetet är politiskt, ekonomiskt och kulturellt förankrat och en viktig del av europeiskt och internationellt samarbete. Den nordiska gemenskapen arbetar för ett starkt Norden i ett starkt Europa.

Det nordiska samarbetet vill styrka nordiska och regionala intressen och värderingar i en global omvärld. Gemensamma värderingar länderna emellan bidrar till att stärka Nordens ställning som en av världens mest innovativa och konkurrenskraftiga regioner.

\section{Nordiska ministerrådet \\ Nordens Hus \\ Ved Stranden 18 \\ 1061 Köpenhamn K \\ www.norden.org}

Ladda ner nordiska publikationer: www.norden.org/nordpub 


\section{Program för utbildning och forskning}

Sveriges ordförandeskap 2018

i Nordiska ministerrådet

04 MINISTERFÖRORD

$05 \quad$ INLEDNING

06 DEN GEMENSAMMA NORDISKA FORSKNINGSPOLITIKEN

09 STRATEGISK ÖVERSYN AV UTBILDNINGSSAMARBETET

11 KVALITET I HÖGRE UTBILDNING

12 VUXNA BEFOLKNINGENS KUNSKAPER OCH KOMPETENS

13 IMPLEMENTERING AV LÄROPLANER I FÖRSKOLAN - VAD FUNGERAR?

14 DIS-NÄTVERKET

15 UNGAS INKLUDERING I SOCIOEKONOMISKT UTSATTA OMRÅDEN

16 ARBETSFORMER FÖR MINISTERRÅDET

17 KALENDER 


\section{MINISTERFÖRORD HELENE HELLMARK KNUTSSON}

Utbildning och forskning står för framtidstro och hopp. Utbildning har blivit tillgänglig för fler människor och forskningen finner svaret på allt fler frågor men i nuläget möter vi alltjämt en orolig omvärld och stora utmaningar för våra samhällen. I oroliga tider som dessa är det viktigare än någonsin att fortsätta satsa på kunskap. Det är en förutsättning för en hållbar demokrati och det rustar människor för att vara aktiva medborgare i ett föränderligt samhälle. Utbildning och forskning bygger också våra samhällen starka och gör oss kapabla att möta de utmaningar som bland annat digitalisering och klimatförändringar innebär. Forskning och forskningsbaserad kunskap är grunden för att kunna möta samhällsutmaningar och skapa en hållbar samhällsutveckling.

De samhällsutmaningar vi står inför måste också mötas med gemensamma krafter. Det har vi god erfarenhet av att göra inom Norden, och det ska vi fortsätta med. Vi är mer lika än olika och när vi arbetar tillsammans i frågor vi är enade i blir vi en än starkare röst än var för sig. Nordiskt samarbete är också något som våra medborgare uppskattar, vilket vi ska värna.

Norden är en liten region långt uppe i norr. Vi ska konkurrera med kompetens, forskning och innovativ förmåga. Genom att sätta kunskap i fokus och arbeta tillsammans sätter vi vår region på världskartan. Att ytterligare stärka Norden som kunskapsregion är också målsättningen med det svenska ordförandeskapet.

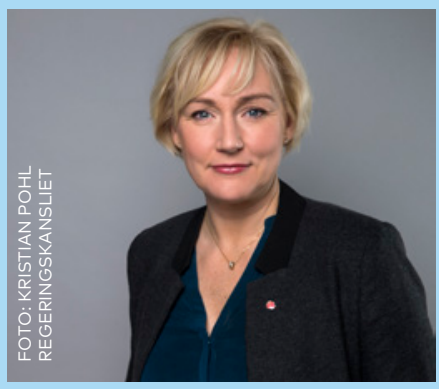




\section{INLEDNING}

Med det svenska ordförandeskapet i Nordiska ministerrådet 2018 vill Sverige arbeta för ett inkluderande, hållbart och innovativt Norden. Ett Norden som ska vara tryggt och öppet. Utbildning och forskning har här en avgörande roll. Att utbildning är inkluderande och tillgänglig för alla är en förutsättning för att människor och samhällen ska utvecklas. Våra utbildningar ska vara hållbara men också kunna ta in de förändringar som sker i samhället. Forskningen är ett av de områden som behöver vara allra mest innovativt och dynamiskt, för att kunna ge svar på de stora samhällsutmaningar vi står inför och gemensamt delar i de nordiska länderna.

Norden är i många avseenden en föregångsregion, känd för sina välfärdssystem, sin goda utbildning och det innovativa klimatet. Det som gör oss unika i Norden ska vi sträva efter att behålla, utan att för den sakens skull vara rädda för förändring när det behövs. För att Norden även framöver ska vara en ledande kunskaps- och kompetensregion behöver vi ständigt arbeta för att tillsammans utveckla och förfina våra system för utbildning och forskning. När vi vill utveckla och förbättra våra system tittar vi i första hand på hur man gör i de andra nordiska länderna. Detta erfarenhetsutbyte är en central del av det nordiska samarbetet och det är en del som vi vill stärka och utveckla under det svenska ordförandeskapet.

Det svenska ordförandeskapet vill stärka det nordiska mervärdet. Det nordiska samarbetet ska fokusera på de områden som hanteras bättre på nordisk nivå än på till exempel europeisk eller global nivå. En annan viktig utgångspunkt för det svenska ordförandeskapet är långsiktighet. Det innebär ett tydligt fokus på strategiskt långsiktiga frågor som stärker grunden i det nordiska samarbetet för utbildning och forskning.

Två stora framtidsfrågor kommer dominera ordförandeskapsåret. Den första är den gemensamma nordiska forskningspolitiken och den andra är högnivågruppens rapport om framtiden för det nordiska utbildningssamarbetet. 


\section{DEN GEMENSAMMA NORDISKA FORSKNINGSPOLITIKEN}

Det forskningspolitiska samarbetet inom MR-U är ett av de tyngsta och äldsta inom Nordiska ministerrådet. Samarbetets nordiska resurser omfattade budgetåret 2017 cirka 122 miljoner DKK, vilket motsvarar cirka $13 \%$ av Nordiska ministerrådets samlade budget. Detta gör det till ett av det finansiellt sett mest omfattande samarbetsområdena inom Nordiska ministerrådet. Den övergripande målsättningen med samarbetet är att bidra till att Norden utvecklas till en ledande kunskapsregion, och att forskningen ifråga bidrar till kunskapsutveckling som är en förutsättning för samhällets, och politikens, utveckling inom många olika sektorer och områden.

Merparten av Nordiska ministerrådets forskningssatsningar kanaliseras genom NordForsk. Syftet med NordForsks verksamhet är att främja ett effektivt nordiskt samarbete inom forskning, forskarutbildning och forskningsinfrastruktur, och därigenom åstadkomma högsta internationella kvalitet på den nya kunskap som produceras. NordForsk utgör i första hand en plattform för samarbete mellan de olika ländernas forskningsfinansiärer; med tanken att NordForsk ska kunna attrahera de nationella forskningsfinansiärerna att delta i och medfinansiera gemensamma forskningssatsningar.

Långsiktighet och nordiskt mervärde bör vara ledstjärnor i NordForsks verksamhet framöver. Det är viktigt att det fortsatt finns ett tydligt mervärde i NordForsks verksamhet, både i förhållande till vad som sker på nationell nivå och vad som sker på europeisk nivå. NordForsks roll och verksamhet behöver förtydligas för att uppnå detta mål. Omfattande nordiska resurser allokeras till finansiärssamarbetet samtidigt som NordForsk inte helt har förmått att etablera en samverkansprocess och ett programutbud som lockat de nationella forskningsfinansiärerna i avsedd utsträckning. Under ordförandeskapsåret kommer Sverige att arbeta vidare med dessa frågor, för att ytterligare förtydliga NordForsks roll och vidareutveckla NordForsks verksamhet vad rör bland annat nordiskt mervärde, förbättrad samverkan och ett ökat kvalitetsfokus. Efter omfattande överläggningar har MR-U enats om en forskningspolitisk redogörelse till Nordiska rådet som tar ställning i ett antal frågor rörande 


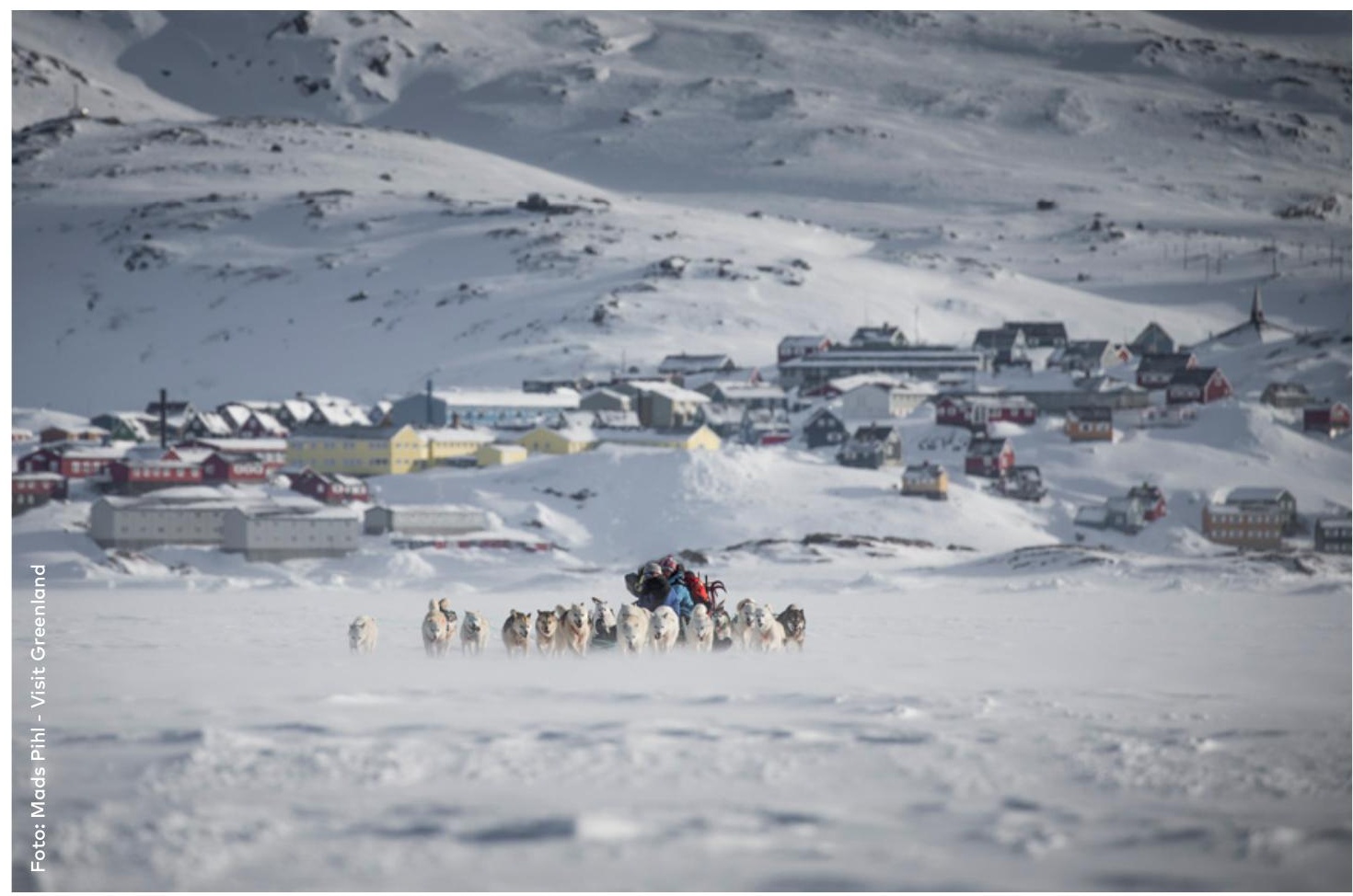

Arktisforskning är en viktig del i det nordiska samarbetet.

forskningssamarbetet och NordForsks verksamhet. Den ad hoc-grupp för forskningssamarbete som tillsattes under 2016 har också lagt fram en rapport under 2017 om forskningssamarbetet. Att implementera ställningstagandena i den forskningspolitiska redogörelsen och ad hoc gruppens rapport och på vissa punkter gå vidare med konkreta uppdrag, samt ta vidare diskussionen från toppmötet vid MR-U 02/2017 den 6 november blir viktiga frågor för det svenska ordförandeskapet.

Under det svenska ordförandeskapet kommer diskussionerna från det norska ordförandeskapet 2017 att tas vidare för att vid MR-U 01/2018 lägga fast en förtydligad inriktning som ger NordForsk klara förutsättningar för verksamheten den kommande treårsperioden. Efter en sådan period bör en utvärdering av verksamheten genomföras.

\section{Konferens om arktisforskning}

Arktis är ett av de geografiska områden som kommer alltmer i fokus. Arktis står i centrum för mycket klimatforskning, eftersom många klimatförändringar kan studeras särskilt gynnsamt i arktiska förhållanden. Samtidigt förändras Arktis geopolitiska situation snabbt då exempelvis nya mineralfyndigheter och 
nya möjliga handelsrutter utforskas. Eftersom de nordiska länderna med sin närhet har en tydlig koppling till arktiska regionen är det naturligt att forskning kring Arktis är viktig inom det nordiska samarbetet, och att sådan forskning har ett tydligt nordiskt mervärde och bidrar till att göra Norden till en ledande kunskapsregion.

Under året planeras en konferens med fokus på arktisforskning där nordiska forskare ges möjlighet att presentera resultaten av aktuell arktisk forskning. Även utomnordiska Arktisforskare kommer att bjudas in till konferensen, som också syftar till att identifiera samarbetsmöjligheter och främja dialog och tvärvetenskapligt samarbete, samt stärka basen för "science diplomacy".

\section{Konferens om open science}

Open Science eller Öppen vetenskap beskriver en process eller en affärsmodell där bland annat forskningsresultat görs öppet tillgängliga, att forskare på andra sätt än tidigare delar sin kunskap, och med ambitionen att det omgivande samhället och medborgarna blir mer delaktiga i forskningen. De nordiska ländernas regeringar har generellt ställt sig positiva till detta och flera av länderna har antagit policyer för öppen tillgång till forskningsresultat, om än i något varierande utformning, och också utifrån delvis varierande förutsättningar vad gäller exempelvis intellektuella rättigheter. Flera av länderna har ställt sig bakom EU:s konkurrentskraftsråds slutsatser om open science.

Flera av de nordiska länderna arbetar således med frågor kring open science. Ökat utbyte av kunskap och erfarenhet inom detta område kan bidra till förhöjd kvalitet i arbetet. En viktig drivkraft för vetenskaplig produktion och inom öppen vetenskap är incitament och belöningssystem. Exempelvis uppstår frågor om hur olika system för open science kan påverka incitamenten för vetenskaplig produktion och hur vetenskapliga resultat kan användas. Andra frågor rör exempelvis det gemensamma forskningsmolnet, och relevant infrastruktur. Sverige kommer under ordförandeskapet att arrangera en konferens om open science för att öka kunskaperna om sådana frågor och vidareutveckla arbetet kring open science och främja utvecklingen av Norden som en ledande kunskapsregion. 


\section{STRATEGISK ÖVERSYN AV UTBILDNINGSSAMARBETET}

Nordiska ministerrådet tillsatte under 2017 en högnivågrupp med uppdraget att göra en strategisk översyn över hur det framtida nordiska samarbetet inom utbildning kan förstärkas och förnyas samt bidra till konkreta svar på dagens och morgondagens utmaningar.

Högnivågruppen presenterade i november 2017 sin rapport som innehåller en mängd förslag på flera olika områden. Rapporten och dess förslag kommer

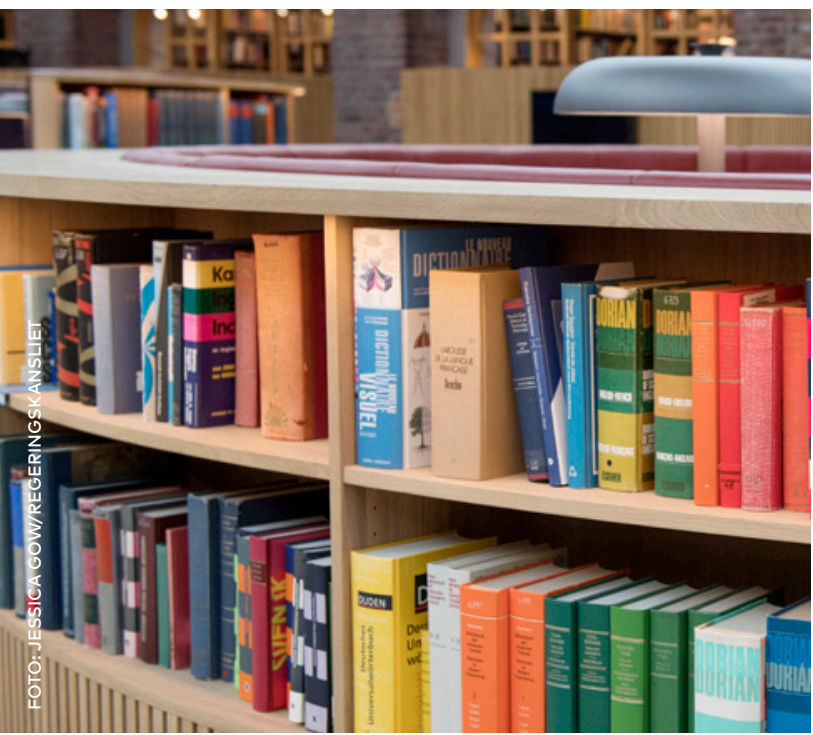

under det svenska ordförandeskapet att följas upp, bl.a. med ett seminarium i hearingformat i början av året. Seminariet, som riktar sig till aktörer i de nordiska länderna som berörs av rapportens förslag, syftar till att inhämta synpunkter på gruppens förslag inför den fortsatta uppföljningen inom ÄK-U och MR-U.

Rapporten utgör en god grund för fortsatt diskussion om framtida samarbete inom utbildning. Förhoppningen är att seminariet därmed skall bidra till att det nordiska samarbetet inom utbildningsområdet är väl förankrat i medlemsländerna liksom i de självstyrande områdena. Ambitionen är att vid MR-U 01/2018, med utgångspunkt i högnivågruppens rapport, ge tydliga riktlinjer och prioriteringar för det fortsatta arbetet med utbildningsfrågor i ministerrådet under de kommande åren. 
.

$$
3
$$

(7) $-\sqrt{2}$

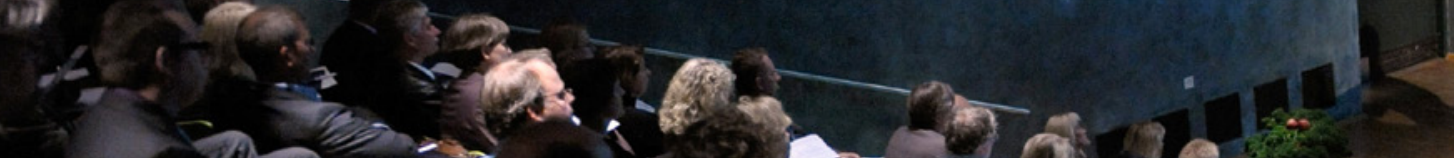

(
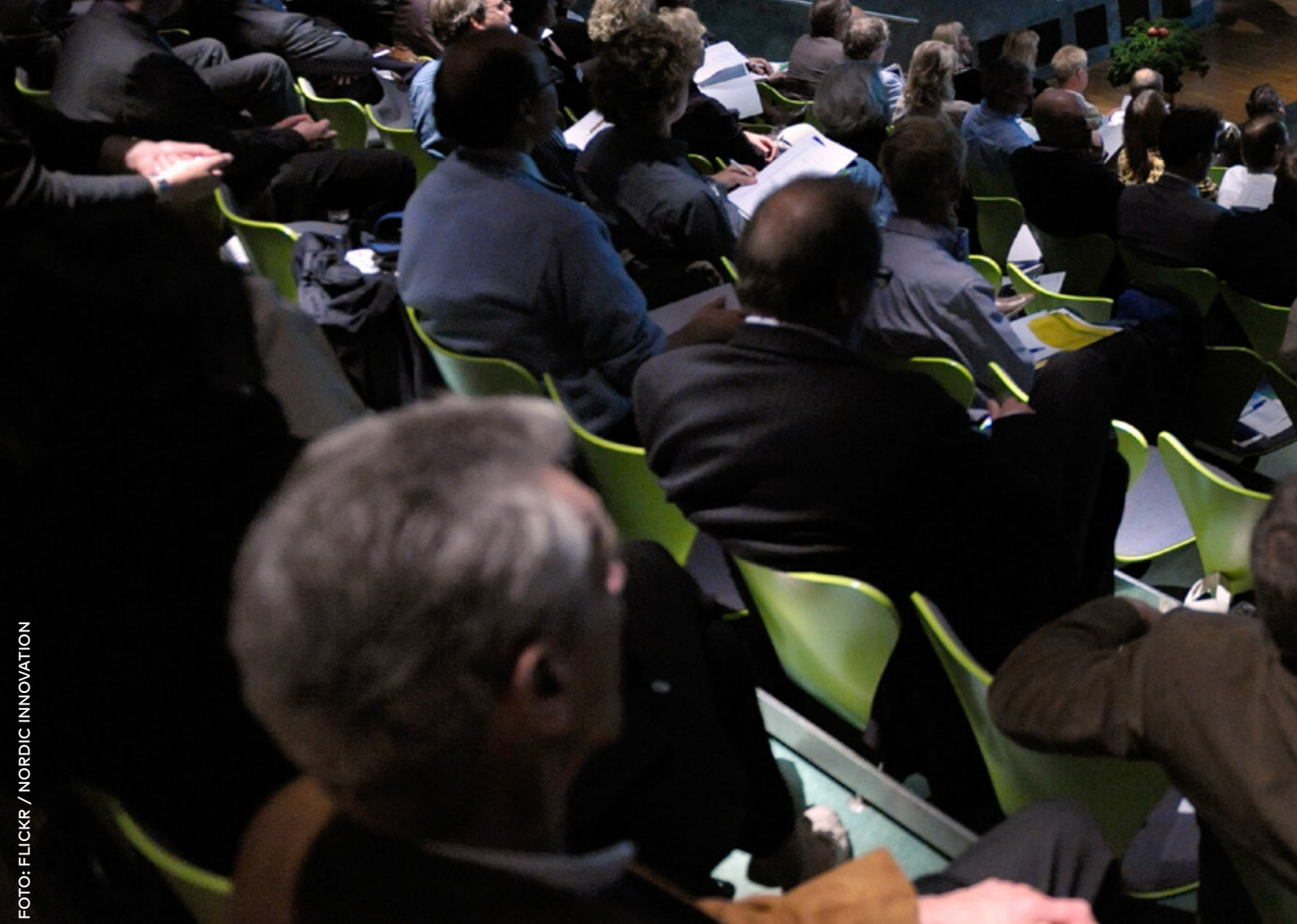


\section{KVALITET I HÖGRE UTBILDNING}

Hög kvalitet i den högre utbildningen är en av grundstenarna för att Norden ska bibehålla sin konkurrenskraft i en snabbt föränderlig omvärld. De nordiska länderna står inför likartade utmaningar och kan dra nytta av varandras erfarenheter och diskutera gemensamma lösningar. Mot den bakgrunden tillsatte Nordiska ministerrådet 2014 en ad hocgrupp med uppdrag att bl.a. ge förslag på hur vi på nordisk nivå kan fördjupa samarbetet om kvalitet inom högre utbildning.

Ad hoc-gruppen, som har representanter från ministerier, myndigheter och lärosäten från de nordiska länderna, presenterade 2016 rapporten Student-centered approach from a Nordic perspective. På gruppens initiativ har ordförandeländerna Finland (2016) och Norge (2017) arrangerat endagskonferenser om kvalitet i högre utbildning. Konferenserna har lockat ett hundratal deltagare och varit ett forum för en bred målgrupp inom högre utbildningsområdet från ministerier, myndigheter, lärosäten och intresseorganisationer.
Möjligheten till studier av hög kvalitet oavsett var man bor är en viktig förutsättning för att ge unga ökade valmöjligheter och för att ge människor senare i livet möjlighet till utbildning, kompetensutveckling och omställning $i$ en ny och föränderlig tid. Det ska vara möjligt att studera i hela landet och under hela livet. Detta är en utmaning som alla nordiska länder delar med varandra. Sverige kommer därför i juni 2018 att arrangera en endagskonferens med inriktning mot kvalitet i det livslånga lärandet.

Bland de förslag som Högnivågruppen presenterat finns tankar om ett utökat samarbete om utbildningsdata och statistik. Under 2018 kommer ad-hocgruppen därför att genomföra en kartläggning av statistik och indikatorer för kvalitet i högre utbildning i de nordiska länderna. 


\section{VUXNA BEFOLKNINGENS KUNSKAPER OCH KOMPETENS}

Uppfyller den vuxna befolkningen nuvarande och framtida behov av kompetens? Det är något som har studerats $i$ OECD-programmet PIAAC. ${ }^{1}$ De första resultaten från den internationella undersökningen av vuxnas färdigheter publicerades 2013.

Forskare, statistikproducenter och experter från nationella vuxenutbildnings-institutioner i Norden har med hjälp av finansiering från Nordiska ministerrådet kunnat etablera ett sär-

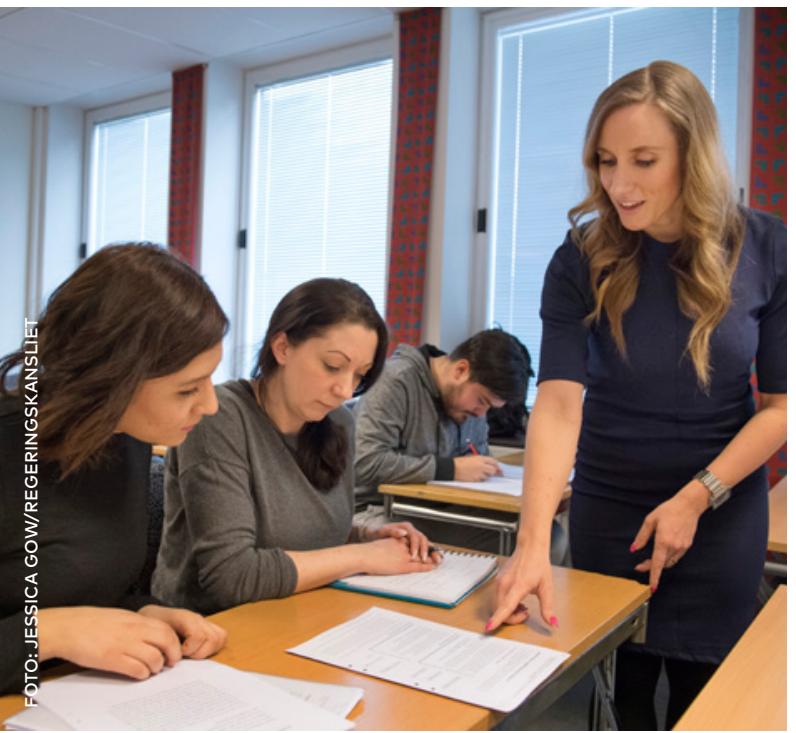

skilt nätverk för PIAAC. Detta nätverk har bl.a. tagit fram en särskild nordisk PIAAC-rapport och skapat en nordisk PIAAC-databas med variabler från undersökningen och från nationella register.

Resultaten från den nordiska PIAACrapporten publicerades 2015 och de visade att de nordiska länderna överlag hade bra resultat när det gäller den arbetsföra befolkningens kunskaper och kompetens, men att det även fanns en relativt stor andel $i$ åldern 16-64 år med låga kunskapsnivåer. Fler nordiska analyser baserat på data från PIAAC-undersökningen har gjorts under de senaste åren.

I slutet av 2018 ska ett expertseminarium arrangeras där resultaten från de nordiska analyserna kommer att presenteras och diskuteras. Seminariet är ett samarrangemang mellan Utbildningsdepartementet och Arbetsmarknadsdepartementet i Sverige.

\footnotetext{
${ }^{1}$ Programme for the International Assessment of Adult Competencies.
} 


\section{IMPLEMENTERING AV LÄROPLANER I FÖRSKOLAN - VAD FUNGERAR?}

Frågan om förskolans läroplan är högaktuell i de nordiska länderna. I både Norge och Finland pågår implementering av nya läroplaner för förskolan, och Sverige står inför ett liknande arbete framöver. Det nordiska förskolenätverket $^{2}$ utgör därför en viktig arena för länderna för att dela erfarenheter och kunskaper om verksam implementering. Under året kommer ett seminarium i nätverket anordnas, där fokus kommer att vara på frågor som implementeringsmetoder och utvärdering av implementeringseffekter och hur skrivningar i läroplanen kan realiseras i praktiken. Även frågan om det är möjligt att skapa data i nationella utvärderingar av implementering för att användas på ett tvärnationellt plan kommer att lyftas. Därutöver kommer EC:s indikatorer för kvalitet i förskolan att presenteras.

\footnotetext{
${ }^{2}$ Det nordiska förskolenätverket (Nordic Network on ECEC) har mötts en till två gånger om året sedan 2007. I nätverket ingår de fem nordiska länderna samt de tre självstyrande områdena. Deltagare är representanter från ministerier och skolmyndigheter som har ansvar för förskola.
}

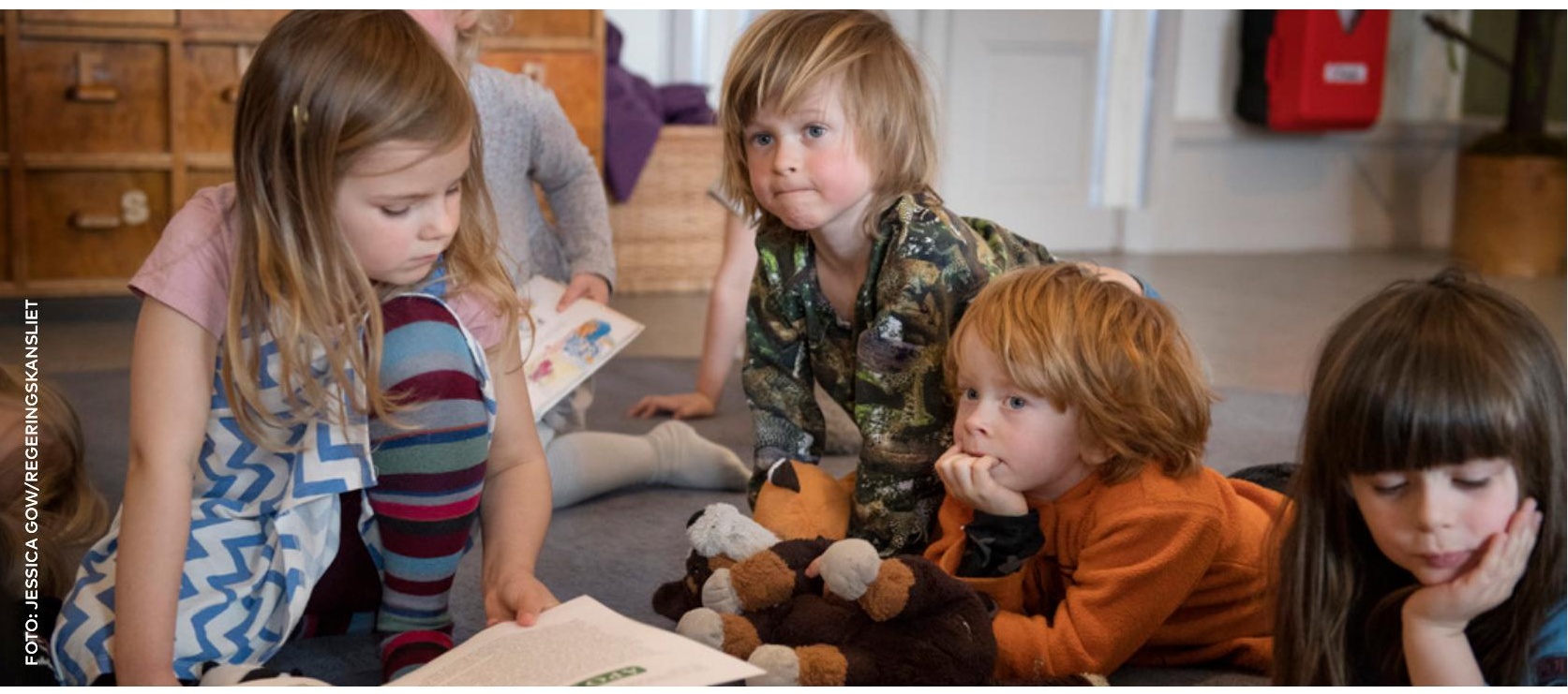




\section{DIS-NÄTVERKET}

Under året kommer DIS-nätverket, som upprättades som en del av det finska ordförandeskapsprojektet Demokrati, Inkludering och Säkerhet 2015, att tas vidare. DIS-nätverket syftar till att via nordiskt erfarenhetsutbyte och samarbete stärka utbildningens roll i att motverka våldsbejakande extremism genom skolans demokratiska uppdrag. Under det svenska ordförandeskapet ligger fokus på forskning och högre utbildning. Detta under temat "Utbildning för demokrati i en orolig tid".
Inom ramen för temat Utbildning för demokrati i en orolig tid planeras under hösten en konferens för forskare, policynivån och praktiker. Syftet är att stärka nordisk samsyn gällande utbildningens roll i demokratin. Dessutom planeras en nordisk antologi om hur lärarutbildning i Norden förbereder lärare för ett demokratiskt uppdrag i en samtid där populism, extremism och falska nyheter är växande utmaningar.

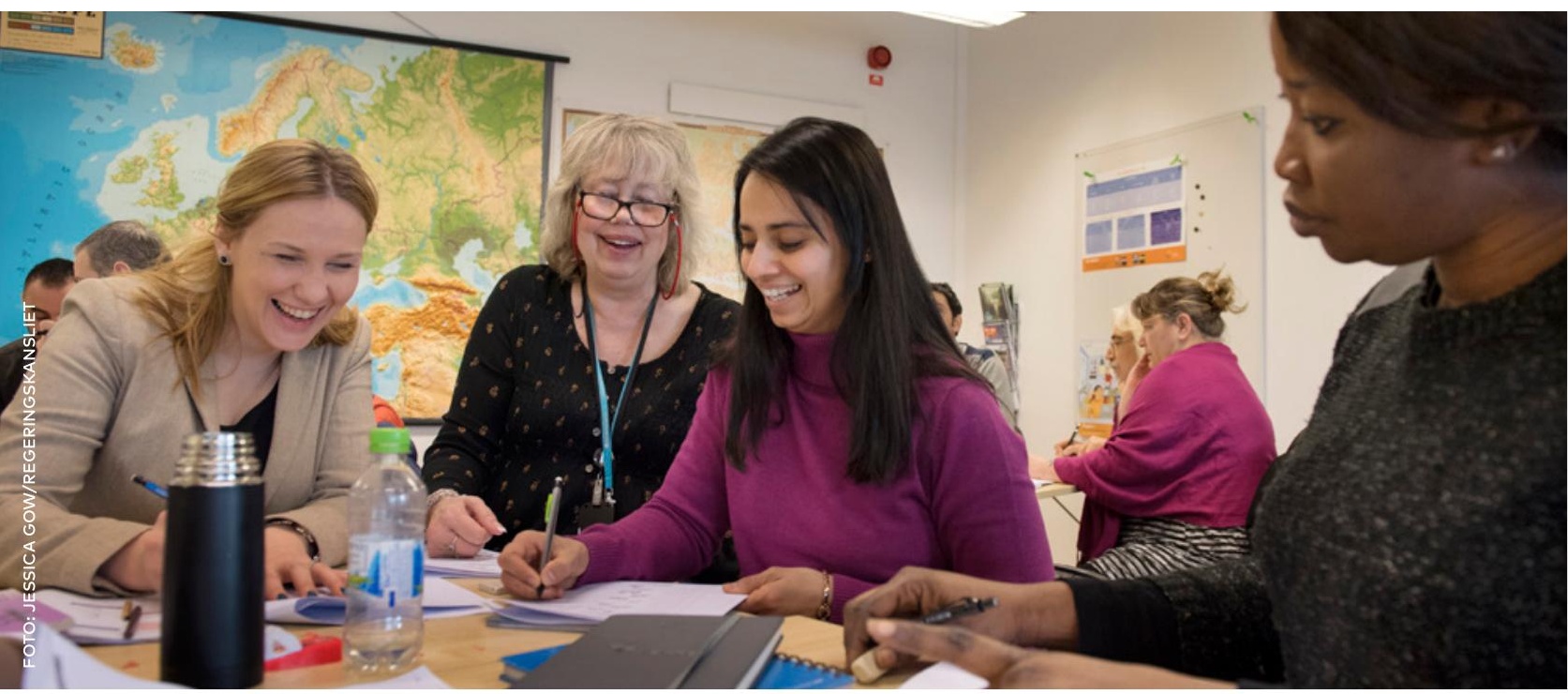




\section{UNGAS INKLUDERING I SOCIO- EKONOMISKT UTSATTA OMRÅDEN}

Nordiska ministerrådets vision är att Norden ska vara den bästa platsen $i$ världen för unga. Detta är något som Sverige tagit fasta på under sitt ordförandeskap genom ordförandeskapsprojektet Ungas inkludering i socioekonomiskt utsatta områden. Syftet med projektet är att synliggöra och arbeta för att minska ojämlikhet och segregation samt öka ungas delaktighet i socioekonomiskt utsatta områden.
När projektet är klart är ambitionen att det finnas en samlad nordisk kunskapsbild av ungas sociala inkludering som utgår ifrån ett ungdomsperspektiv. Unga ska integreras aktivt i arbetet med projektet. Myndigheten för ungdoms- och civilsamhällesfrågor genomför projektet och kommer att ta hjälp av forskare, tjänstemän i offentlig sektor och andra experter för att, utifrån det som unga själva beskriver, ta fram arbetssätt, strukturer och policys i syfte att förändra och förebygga de problem som leder till social exkludering.

En konferens om ungas sociala inkludering planeras genomföras under senare delen av 2018. Konferens ska samla experter, forskare och unga från de nordiska länderna. 


\section{ARBETSFORMER FÖR MINISTERRÅDET}

Ett ministermöte planeras under året. Mötesformerna för ministermötena har diskuterats en tid, och Sveriges avsikt är att göra dessa möten så relevanta som möjligt för de deltagande ministrarna. Dels ska diskussionsteman förankras bättre med ministrarna inför mötet, dels ska upplägget främja informell diskussion och relevant erfarenhetsutbyte mellan ministrarna i aktuella frågor, förslagsvis genom att delar av mötet hålls i mindre krets eller att en "inner circle" tillämpas. Diskussionsteman för mötet ske ge ett mervärde nationellt och bidra till att lösa de nordiska länderna och självstyrande områdenas utmaningar på utbildningsområdet. Sverige kommer också ta i beaktande högnivågruppens förslag om att det bör finnas fler möjligheter att diskutera strategiskt, långsiktigt och visionärt samarbete vid ministermötena.

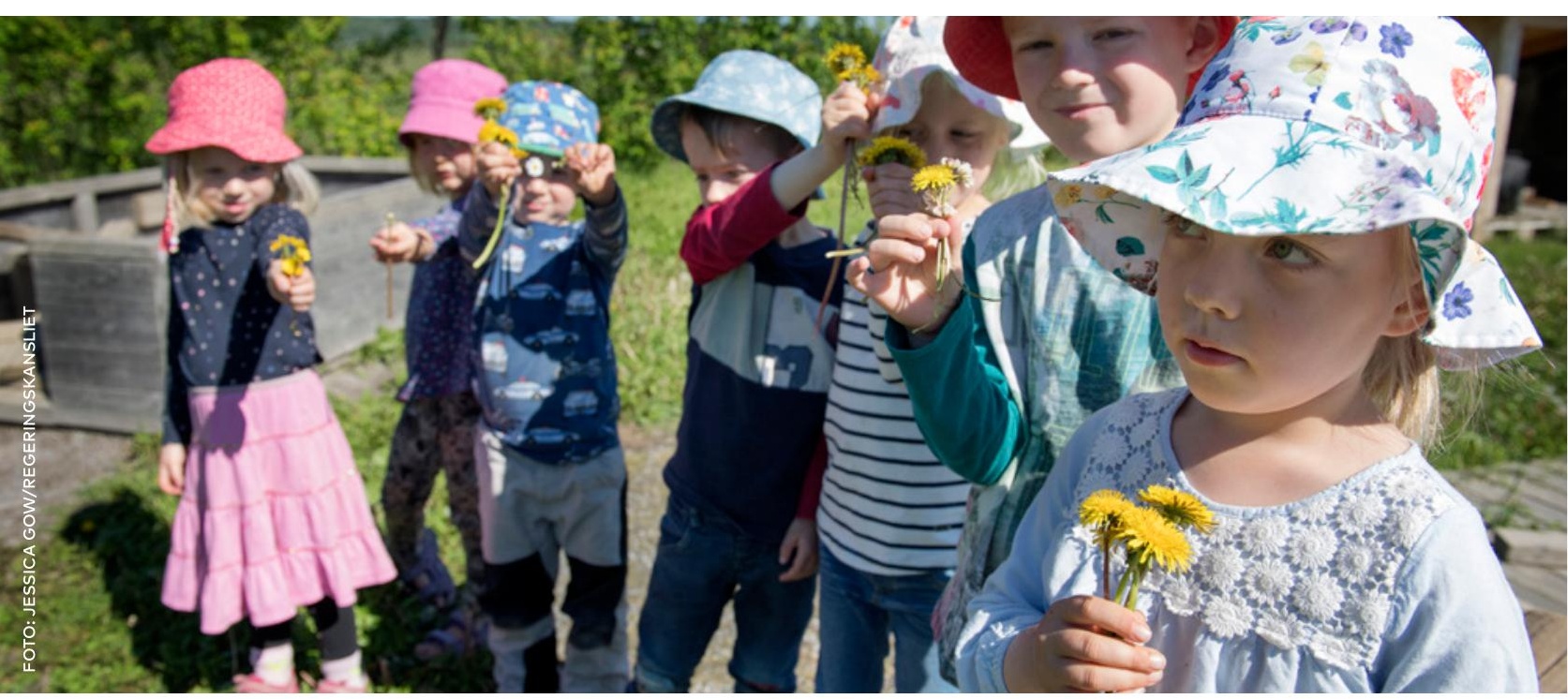




\section{KALENDER}

MÖTE/KONFERENS/SEMINARIUM

ÄK-U 1 01/2018

Remisshearing om högnivågruppens rapport om framtida nordiskt utbildningssamarbete

MR-U 1 01/2018

Seminarium om implementering av förskolans läroplan

ÄK-U 2 02/2018

Konferens om kvalitet i högre utbildning

Direktörsmöte

ÄK-U 3 03/2018

Konferens om open science

Konferens inom ramen för DIS-

projektet: Utbildning för demokrati

i en orolig tid
TIDPUNKT

20 februari

15 mars (prel.)

25 april

$23-24$ maj

$12-13$ juni

13 juni (prel.)

$30-31$ augusti

20 september

Oktober/november

29 - 30 november
PLATS

Köpenhamn, DK

Stockholm, SE

Stockholm, SE

Stockholm, SE

Lund, SE

Stockholm, SE

Lidingö, SE

Stockholm, SE

Örebro, SE 
MÖTE/KONFERENS/SEMINARIUM

Nordiskt expertseminarium som presenterar resultat från nordisk forskning baserat på data från

PIAAC-databasen

ÄK-U 4 04/2018

(Preliminärt - under utarbetande) Spridningskonferens om ungas sociala inkludering

(Preliminärt - under utarbetande) Konferens om Arktisforskning
PLATS

November/december

Stockholm, SE

5 december

November/december

Datum ej satt
Köpenhamn, DK

Hanaholmen, Fi 


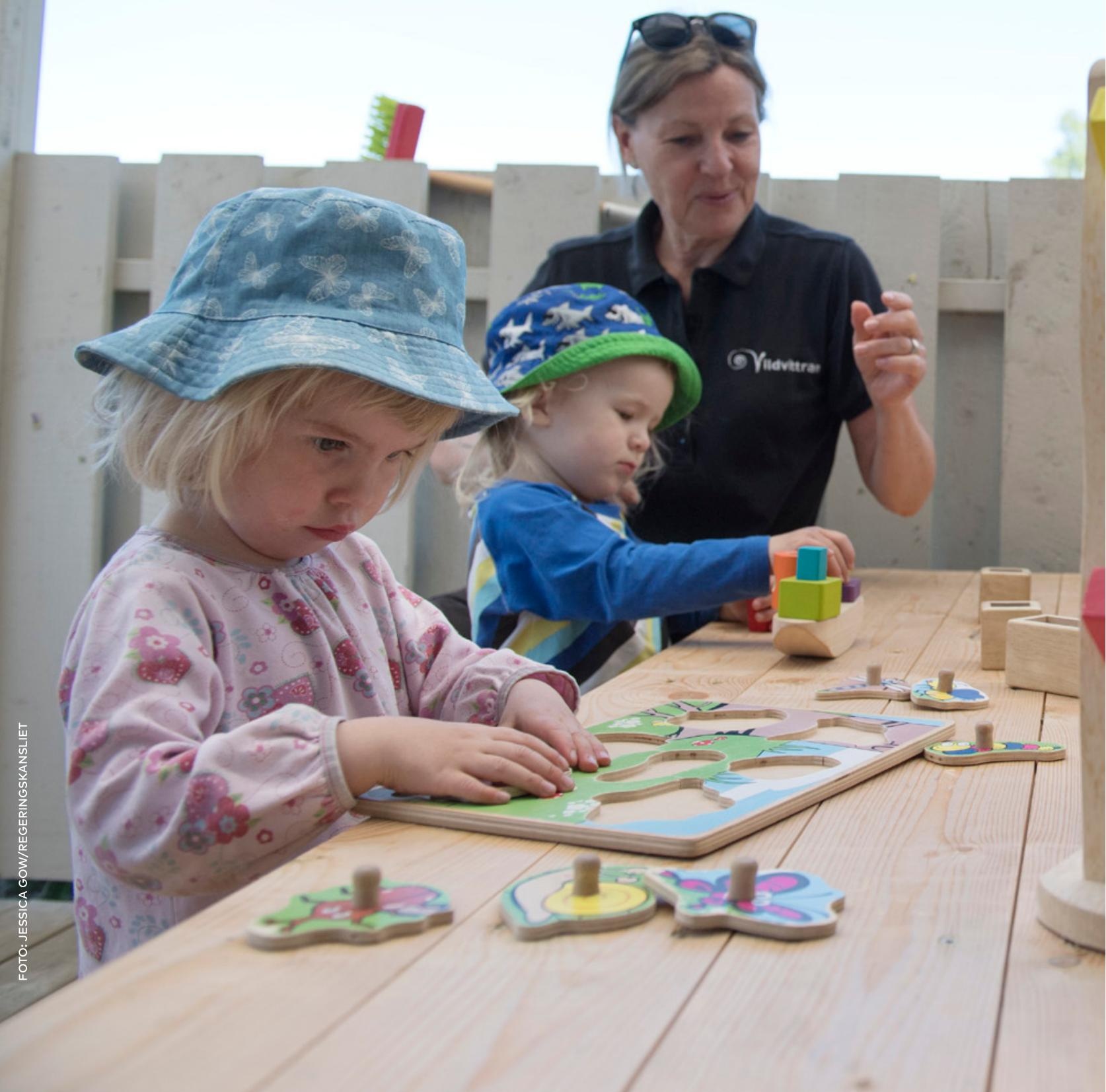


Nordiska ministerrådet

Nordens Hus

Ved Stranden 18

DK-1061 Köpenhamn K

www.norden.org

ANP 2017:787

ISBN 978-92-893-5292-5 (PRINT)

ISBN 978-92-893-5293-2 (PDF)

ISBN 978-92-893-5294-9 (EPUB) 